\title{
PENANAMAN NILAI KARAKTER PADA PEMUDA (MAHASISWA) MELALUI PEMBELAJARAN MKU BAHASA INDONESIA*
}

\author{
Agus Budi Santoso, Dwi Rohman Soleh, dan Eni Winarsih \\ FPBS IKIP PGRI Madiun \\ e-mail: agusbudisantoso994@yahoo.co.id
}

\begin{abstract}
Abstrak
Penelitian ini bertujuan untuk mendeskripsikan penanaman nilai karakter pemuda (mahasiswa) melalui pembelajaran MKU Bahasa Indonesia.

Metode yang digunakan dalam penelitian ini adalah deskriptif kualitatif. Data dikumpulkan melalui angket pengembangan karakter, dan observasi pada saat pembelajaran MKU Bahasa Indonesia berlangsung.

Hasil penelitian menunjukkan bahwa penanaman karakter pada pemuda (mahasiswa) melalui pembelajaran MKU Bahasa Indonesia di IKIP PGRI Madiun dilakukan sebagai salah satu bentuk pelaksanaan pendidikan karakter, yang dalam pelaksanaannya dilakukan dengan cara memasukkan sembilan nilai karakter dari 18 karakter yang ada. Nilai-nilai karakter tersebut adalah (1) nilai religius, (2) kejujuran, (3) disiplin, (4) kerja keras, (5) kreatif, (6) cinta tanah air, (7) gemar membaca, (8) peduli lingkungan, dan (9) tanggung jawab. Nilai-nilai tersebut dipandang penting bagi seorang mahasiswa sebagai pemuda calon pemimpin bangsa. Oleh karena itu, kesembilan nilai karakter ini harus ditanamkan dalam diri pemuda (mahasiswa) melalui pembelajaran MKU Bahasa Indonesia. Dosen menanamkan nilai-nilai karakter melalui tugas-tugas menulis ilmiah selama perkuliahan berlangsung.
\end{abstract}

Kata kunci: penanaman nilai karakter, dan pembelajaran MKU Bahasa Indonesia

\begin{abstract}
The research aimed to describe how to establish character value on youth (university students) through learning Indonesian as a college subject. The reserach method was descriptive qualitative. Data were collected through using questionnaires of character value and observation during the Indonesian teaching learning was in progress.

The results showed that establishing character value on youth (university students) became one of ways to provide character education. There were 9 character values of 18 character values to be inserted in the teaching learning process. They were (1) religious value, (2) honest, (3) discipline, (4) hardworker, (5) creative, (6) respecting for the country of origin, (7) reading much, (8) care for the environment, and (9) having responsible. The character values above were needed by the students as candidates of nation leaders. These nine character values, therefore, should be established in the students' minds through learning Indonesian subject. Lecturers inserted caracter values in the teaching learning process during assigning the students to compose scientific writing. Keywords: establishing character values and learning Indonesian as a college subject
\end{abstract}

\section{Pendahuluan}

Menurut Patria (2010: 1), pendidikan karakter, akhir-akhir ini, semakin sering menjadi pembahasan berbagai kalangan, terutama kalangan pendidikan. Hal ini terdorong oleh adanya fakta bahwa siswa sebagai produk pendidikan 
belum kuat secara kemanusiaan, serta kepribadiannya masih lemah, mudah terpengaruh. Selain itu, semangat untuk belajar, berdisiplin, beretika, bekerja keras, dan sebagainya kian menurun. Peserta didik banyak yang tidak siap untuk menghadapi kehidupan sehingga dengan mudah meniru budaya luar yang negatif, terlibat di dalam amuk massa, melakukan kekerasan di sekolah atau kampus, dan sebagainya.

Mahasiswa demo dengan berbuat anarkhis, seperti merusak dan membakar fasilitas kampus. Mahasiswa yang menjual diri untuk memenuhi kebutuhan dirinya. Adanya seks bebas di kalangan mahasiswa yang terjadi di berbagai kota di Indonesia. Peristiwa mahasiswa yang membunuh dosennya di Medan. Semakin menambah daftar panjang adanya kemerosotan karakter. Semua terjadi karena mahasiswa telah "kehilangan karakternya". Kondisi ini menimbulkan kecurigaan masyarakat mengenai kegagalan pendidikan. Pendidikan selama ini lebih cenderung memberikan porsi yang berlebih pada penanaman aspek-aspek kompetensi hard skills dan kurang memberi porsi yang layak pada penanaman soft skills.

Menurut Bali (2012: 803), untuk memperbaiki moralitas dan karakter mahasiswa, maka pendidikan karakter yang telah diajarkan bukan hanya sebagai sebuah teori pembelajaran tetapi sebuah praktik kehidupan mahasiswa ketika belajar di kampus. Sudah saatnya pendidikan karakter di perguruan tinggi berfungsi membendung degradasi karakter dan membentuk karakter mahasiswa yang kokoh guna menghadapi berbagai tantangan masa depan. Pendidikan karakter pun menjadi daya pendorong bagi para mahasiswa untuk menjadi intelektual muda bangsa yang memiliki kepribadian unggul, sebagaimana dimuat dalam undang-undang pendidikan nasional. Perguruan tinggi memiliki dua unsur utama, yaitu dosen dan mahasiswa. Kedua unsur ini perlu memiliki orientasi ke arah perkembangan budaya akademik. Keduanya pun diikat dalam etika akademik yang tumbuh dari nilai-nilai luhur dan berujung pada terbentuknya budaya akademik. 
Makalah ini menguraikan bagaimana menanamkan nilai karakter pada pemuda (mahasiswa) melalui pembelajaran MKU Bahasa Indonesia di IKIP PGRI Madiun. Melalui penanaman karakter tersebut diharapkan pemuda (mahasiswa) sebagai calon pemimpin bangsa memiliki karakter yang baik dalam berkehidupan berbangsa, bernegara, dan mampu menjadi contoh yang baik dalam kehidupannya di masyarakat.

Menurut Khan (2010:1) karakter adalah sikap pribadi yang stabil hasil proses konsolidasi secara progresif dan dinamis, integrasi pernyataan dan tindakan. Karakter dapat juga diartikan moral. Jika ditinjau dari asal bahasanya kata moral berasal dari bahasa Latin mores. Mores berasal dari kata mos yang berarti kesusilaan, tabiat atau kelakuan (Salam, 2000: 80). Sedangkan karakter berasal dari kata charasein yang berarti mengukir. Dengan demikian karakter dan moral memiliki makna yang sama, yaitu keduanya sama-sama melekat pada diri seseorang dan menjadi ciri khas sikap seseorang.

Menurut Pateda (2014: 80), karakter dimaknai sebagai cara berpikir dan berperilaku yang khas tiap individu untuk hidup dan bekerja sama, baik dalam lingkup keluarga, masyarakat, bangsa, dan negara. Scerenko (dalam Samani dan Hariyanto, 2012:42) mendefinisikan karakter sebagai atribut atau ciri-ciri yang membentuk dan membedakan ciri pribadi, ciri etis, dan kompleksitas mental dari seseorang, atau suatu kelompok, atau bangsa. Pada halaman yang sama Robert Marine mengambil pendekatan yang berbeda terhdapa makna karakter, menurut dia karakter adalah gabungan yang samar-samar antara sikap, perilaku bawaan, dan kemampuan yang membangun pribadi seseorang.

Lebih lanjut, Samani dan Hariyanto (2012:43) mendefiniskan karakter sebagai nilai dasar yang membangun pribadi seseorang, terbentuk baik karena pengaruh hereditas maupun pengaruh lingkungan, yang membedakannya dengan orang lain, serta diwujudkan dalam sikap dan perilakunya dalam kehidupan sehari-hari. Pengertian tersebut menekankan dua hal, yakni karakter menjadi pembeda seseorang dengan orang lain, dan karakter diimplementasikan dalam kehidupan sehari-hari. 
Tidak dapat dipungkiri bahwa setiap karakter memiliki nilai-nilai yang terkandung di dalamnya. Menurut Asmani (2011:36) berdasarkan kajian berbagai nilai agama, norma sosial, hukum, etika akademik, dan prinsip-prinsip HAM telah teridentifikasi butir-butir nilai yang dikelompokkan menjadi lima nilai utama, yaitu:

1. Nilai karakter dalam hubungannya dengan Tuhan.

2. Nilai karakter dalam hubungannya dengan diri sendiri, meliputi jujur, bertanggung jawab, disiplin, kerja keras, percaya diri, kritis, kreatif, inovatif, dan sebagainya.

3. Nilai karakter yang berhubungan dengan sesama, meliputi patuh pada aturan, sopan, menghargai orang lain, sadar hak dan kewajiban, dan sebagainya.

4. Nilai karakter yang berhubungan dengan lingkungan, yaitu sikap yang berhubungan dengan segala upaya menjaga kelestarian lingkungan.

5. Nilai kebangsaan, meliputi nasionalis dan menghargai keberagaman.

Pendidikan karakter muncul karena adanya keprihatinan terhadap pendidikan yang ada selama ini. Selain itu, adanya krisis moral yang melanda bangsa ini menjadi faktor utama dicetuskannya pendidikan karakter. Dengan dicanangkannya pendidikan karakter diharapkan dapat mengurangi krisis moral yang sedang melanda bangsa Indonesia.

Uraian tersebut menunjukkan bahwa pendidikan karakter akan selalu mengukur semua perilaku berdasarkan nilai yang ada yang menggambarkan bahwa seseorang yang berkarakter akan memiliki keberanian dalam mengambil keputusan secara bertanggung jawab, memiliki motivasi dan keberanian dalam mengambil resiko dan tidak mudah terombang-ambing karena sebuah prinsip yang telah dipegang. Dari sinilah seseorang yang berkarakter akan memiliki otonomi dan keteguhan dan kesetiaan.

Pada dasarnya pendidikan karakter memiliki makna yang sama dengan pendidikan moral. Karena karakter dapat juga diartikan sebagai moral atau tabiat. Selain itu pendidikan karakter/ pendidikan moral sama-sama bertujuan untuk membekali siswa agar memiliki budi pekerti yang luhur. 
Pendidikan karakter mengajarkan kebiasaan cara berpikir dan berperilaku yang membantu setiap individu atau mahasiswa untuk hidup dan bekerjasama sebagai keluarga, masyarakat, dan negara. Selain itu juga membantu pemuda untuk membuat sebuah keputusan dan mempertanggungjawabkannya. Dengan kata lain pendidikan karakter mengajarkan pemuda (mahasiswa) untuk berpikir cerdas dan mengaktivasi otak tengah secara alami.

Tujuan pendidikan karakter adalah penanaman nilai dalam diri mahasiswa dan pembaharuan tata kehidupan bersama yang lebih menghargai kebebasan individu. Selain itu pendidikan karakter juga bertujuan meningkatkan mutu penyelenggaraan dan hasil pendidikan di kampus yang mengarah pada pencapaian pembentukan karakter dan akhlak mulia peserta didik secara utuh, terpadu, dan seimbang sesuai dengan standar kompetensi lulusan (Asmani, 2011: 42-43). Melalui pendidikan karakter, diharapkan mahasiswa secara mandiri mampu meningkatkan dan menggunakan pengetahuannya, mengkaji dan menginternalisasi serta mempersonalisasi nilai-nilai karakter dan akhlak mulia sehingga terwujud dalam perilaku sehari-hari.

Pada dasarnya pendidikan karakter terdiri dari beberapa jenis. Dalam dunia pendidikan dikenal adanya empat jenis pendidikan karakter, yaitu sebagai berikut.

1. Pendidikan karakter berbasis nilai religius yang merupakan kebenaran dari Tuhan.

2. Pendidikan karakter berbasis nilai budaya.

3. Pendidikan karakter berbasis lingkungan (konservasi lingkungan).

4. Pendidikan karakter berbasis potensi diri (Khan, 2010:2).

Uraian di atas menjelaskan kepada kita bahwa dalam dunia pendidikan diajarkan tentang kehidupan beragama. Hal-hal yang diajarkan dalam agama bersifat dogma, yakni bahwa kebenaran dalam agama tidak dapat disangkal. Pendidikan karakter berbasis nilai budaya menjelaskan kepada kita bahwa dalam pendidikan tidak dapat dilepaskan dari unsur budaya yang melingkupi. Pendidikan karakter bagi orang Jawa tentu akan berbeda dengan budaya lain, selain budaya 
Jawa. Pendidikan karakter berbasis lingkungan lebih merujuk pada pemahaman akan pentingnya menjaga lingkungan sekitar. Anak diajarkan bagaimana melestarikan dan menjaga alam dengan benar. Tidak merusak tanaman dan memiliki kepedulian terhadap kebersihan lingkungan sekitarnya. Pendidikan karakter yang berhubungan dengan potensi diri lebih difokuskan bagaimana anak lebih dapat bertanggung jawab, jujur, dan disiplin terhadap dirinya. Anak diajarkan bagaimana dapat jujur dan bertanggung jawab atas segala perbuatan yang telah dilakukan. Hal ini akan melatih anak dalam mengembangkan potensi dirinya.

Tujuan pendidikan karakter adalah penanaman nilai karakter dalam diri mahasiswa dan pembaharuan tata kehidupan bersama yang lebih menghargai kebebasan individu. Selain itu pendidikan karakter juga bertujuan meningkatkan mutu penyelenggaraan dan hasil pendidikan di kampus yang mengarah pada pencapaian pembentukan karakter dan akhlak mulia peserta didik secara utuh, terpadu, dan seimbang sesuai dengan standar kompetensi lulusan (Asmani, 2011:42-43).

Menurut Pateda (2014: 80), bergulirnya pendidikan yang berbasis karakter menandakan bahwa ada nilai yang selama ini telah hilang dari dunia pendidikan. Betapa tidak, jika diperhatikan beberapa tahun terakhir sasaran akhir pembelajaran lebih ditekankan pada aspek kognitif. Persoalan sikap seakan telah diabaikan, sehingga lulusan SMA atau perguruan tinggi banyak yang tidak dikategorikan tidak bermoral. Apabila hal ini terus dibiarkan, maka bukan hal mustahil jika suatu saat akan terlahir masyarakat yang tidak bermoral.

Oleh karena itu, menurut Pateda (2014: 80), pendidikan karakter yang perlu dikembangkan adalah penanaman nilai dalam diri mahasiswa, baik itu nilai ketuhanan, nilai kemanusiaan, maupun nilai tentang alam. Pembiasaan dan pembentukan sikap akan hal-hal yang baik akhirnya akan membentuk karakter mahasiswa. Pembinaan karakter melalui proses perkuliahan sangat strategis dan tepat dilakukan. Mahasiswa akan tunduk dan patuh pada aturan main perkuliahan 
yang ditetapkan dosen di awal pertemuan. Dosen yang menetapkan suatu aturan main perkuliahan, pada dasarnya ia membentuk karakter mahasiswa, yakni karakter untuk disiplin dan jujur. Menurut penulis, karakter yang perlu dikembangkan adalah nilai religius, kejujuran, disiplin, sosial, mandiri, tanggung jawab, menghargai orang lain, dan nilai-nilai karakter yang lain sebagaimana yang ada dalam 18 nilai karakter bangsa.

Pembentukan dan pembinaan karakter mahasiswa melalui perkuliahan sejalan dengan pendapat MH Ainun Najib (dalam Darwis, 2013: 185) bahwa pengajaran dan pembentukan karakter mahasiswa seyogiyanya dilakukan secara terpadu dengan matakuliah. Pandangan ini memberikan peluang dan kreativitas kepada dosen untuk mendesain pelaksanaan perkuliahan yang mengarah pada pembentukan dan pembinaan karakter mahasiswa.

Jika pembelajaran bahasa adalah juga sebuah proses pembentukan karakter manusia, maka pembelajaran bahasa Indonesia pada dasarnya merupakan sebuah proses pembentuk seorang individu menjadi manusia yang memiliki karakter Indonesia (Pateda, 2014: 80). Jika karakter orang Indonesia dianggap sebagai karakter yang ideal, maka pembentukan karakter Indonesia melalui bahasa Indonesia merupakan sebuah proses kebudayaan yang perlu didukung (Putra, dkk. 2013:xiv ).

Sofyan (2011) berpendapat bahwa mahasiswa sebagai pemuda merupakan asset bangsa, sebagai intelektual muda calon pemimpin masa depan. Sehubungan dengan hal tersebut Direktur Jendral Pendidikan Tinggi pada pengarahan Rakornas Bidang Kemahasiswaan Tahun 2011, menegaskan bahwa pembimbingan mahasiswa diprioritaskan pada: (1) Pengembangan kemampuan intelektual, keseimbangan emosi, dan penghayatan spritual mahasiswa, agar menjadi warga negara yang bertanggung jawab serta berkontribusi pada daya saing bangsa; (2) Pengembangan mahasiswa sebagai kekuatan moral dalam mewujudkan masyarakat madani yang demokratis, berkeadilan, dan berbasis pada partisipasi publik; (3) Peningkatan 
kualitas sarana dan prasarana untuk mendukung pengembangan dan aktualisasi diri mahasiswa; kognisi, personal, sosial. Bila diperhatikan arah pembimbingan mahasiswa tersebut adalah pembentukan kapasitas dan jati diri mahasiswa yang antara lain diwujudkan dalam sikap, perilaku, kepribadian, dan karakter yang terpuji.

Lebih lanjut Sofyan (2011) menyatakan bahwa pembinaan kemahasiswaan melalui berbagai kegiatan diharapkan dapat menghasilkan sosok mahasiswa yang (1) cerdas komprehensif (cerdas spiritual, emosional/sosial, intelektual, dan kinestetik), (2) memiliki kemauan dan kemampuan untuk berkompetisi, (3) memiliki kemampuan untuk menuangkan daya kreasi, (4) mampu untuk menangkap ide-ide dosen dan perkembangan lingkungan, (5) tanggap dan memiliki sensitivitas terhadap realita kehidupan di masyarakat, dan (6) mendapatkan kesempatan untuk menggunakan fasilitas-fasilitas dan membangun jaringan baik di dalam dan di luar kampus (dalam https://www.scribd.com/doc/296682810/BUKU-Pendidikan-Karakter-bagi-

Mahasiswa-UNY-pdfdiunduh pada 4 Agustus 2016).

Pendidikan memang bukanlah sekadar transfer pengetahuan (transfer of knowledge), tapi alat wahana pembentukan kepribadian (character building), mulai dari pola pikir, kejiwaan dan pola tingkah laku (attitude). Oleh sebab itu, muncullah kesadaran tentang perlu dikembangkannya kembali pendidikan karakter di sekolah (Santoso, Dwi Rohman Soleh, dan Eni Winarsih 2015: 1).

Salah satu jalan yang dapat ditempuh untuk menanamkan dan membentuk karakter adalah melalui pembelajaran MKU Bahasa Indonesia. Mahasiswa diharapkan mampu menulis ilmiah, berupa artikel, makalh, dan proposal Program Kreativitas Mahasiswa (PKM). Penanaman dan pengembangan karakter mahasiswa melalui pembelajaran MKU Bahasa Indonesia di IKIP PGRI Madiun dilakukan sebagai salah satu bentuk pelaksanaan pendidikan karakter, yang dalam pelaksanaannya tetap memperhatikan prinsip dasar etika yang harus dimiliki. 
Dosen menjelaskan kepada mahasiswa tentang prinsip dasar etika yang ada pada setiap manusia. Mengidentifikasi karakter secara menyeluruh dalam kehidupan, baik dalam berpikir, berperasaan, dan berperilaku. Ini artinya kita harus mempertimbangkan segala hal terhadap pikiran, perasaan, dan tindakan yang dilakukan secara baik, tidak menyimpang. Hal ini bisa dilakukan dengan memperhatikan pendekatan yang dilakukan dalam mengembangkan karakter mahasiswa. Dosen harus proaktif dalam mengembangkan karakter kepada mahasiswanya, efektif dalam membentuk kepribadian mahasiswa dengan sesuatu yang baik sehingga tercipta komunitas kampus yang memiliki kepedulian terhadap pembentukan karakter dengan bentuk perilaku yang baik yang bisa ditunjukkan oleh mahasiswa. Misalnya etika ketika mahasiswa melakukan wawancara dengan narasumber ketika melakukan penelitian, etika ketika presentasi dan diskusi, dan sebagainya.

\section{METODOLOGI}

Penelitian ini menggunakan metode penelitian deskriptif kualitatif, yaitu prosedur penelitian yang menghasilkan data deskriptif berupa kata-kata tertulis atau lisan dari orang-orang dan perilaku yang dapat diamati. Sumber data yang utama adalah mahasiswa IKIP PGRI Madiun yang menempuh MKU Bahasa Indonesia.

Data dikumpulkan dari hasil penyebaran angket tentang penanaman karakter mahasiswa dan pengamatan pembelajaran MKU Bahasa Indonesia pada mahasiswa IKIP PGRI Madiun. Teknik analisis data yang digunakan dalam penelitian ini adalah deskriptif kualitatif. Teknik analisis data dilakukan setelah ditemukan data hasil pengamatan berupa lembar pengamatan sikap mahasiswa selama dan setelah pembelajaran MKU Bahasa Indonesia.

\section{PEMBAHASAN}

Nilai-nilai karakter bangsa yang akan dikaji dalam makalah ini adalah (1) nilai religius, (2) kejujuran, (3) disiplin, (4) kerja keras, (5) kreatif, (6) cinta tanah air, (7) gemar membaca, (8) peduli lingkungan, dan (9) tanggung jawab. Nilai- 
nilai tersebut dipandang penting bagi seorang mahasiswa sebagai pemuda calon pemimpin bangsa yang akan menjadi dasar bagi kehidupannya. Oleh karena itu, kesembilan nilai karakter ini harus ditanamkan dalam diri mahasiswa melalui perkuliahan MKU Bahasa Indonesia.

Nilai religius mengacu kepada sikap dan perilaku yang patuh dalam melaksanakan ajaran agama yang dianutnya, toleran terhadap pelaksanaan ibadah agama lain, dan hidup rukun dengan pemeluk agama lain. Nilai religius juga bisa diwujudkan dengan perilaku keimanan dan rasa syukur yang dimiliki oleh seorang pemuda (mahasiswa). Bentuk-bentuk yang bisa dilakukan oleh dosen dalam menanamkan nilai karakter religius di kalangan mahasiswa melalui perkuliahan MKU Bahasa Indonesia, salah satunya adalah mengingatkan untuk selalu bersyukur kepada Tuhan atas berkah berupa bahasa Indonesia yang hingga saat ini kita gunakan. Ungkapan rasa syukur dan bangga menggunakan bahasa Indonesia ini bisa dituangkan dalam bentuk tulisan essay. Ini berarti selain menanamkan nilai religius yang dituangkan dalam ungkapan rasa syukur, dosen juga mengoptimalkan kemampuan menulis mahasiswa.

Nilai kejujuran merupakan perilaku yang didasarkan pada upaya menjadikan dirinya sebagai orang yang selalu dapat dipercaya dalam perkataan, tindakan, dan pekerjaan. Seorang pemuda (mahasiswa) harus jujur baik perkataan maupun tindakannya, dan ini kan mendasari bagiamana dia nanti menjadi seorang pemimpin bangsa yang dapat dipercaya dalam mengemban tugas-tugasnya. Nilai karakter kejujuran bisa ditanamkan melalui satu bentuk tugas menulis yang diberikan oleh dosen. Tugas berupa kegiatan melaporkan hasil membaca yang dilakukan di perpuustakaan. Mahasiswa harus jujur menuliskan apa yang telah dibacanya di perpustakaan. Dosen memeriksa kehadiran mahasiswa di perpustakaan dan mencocokkan dengan hasil tulisannya berupa menulis laporan.

Nilai disiplin merupakan tindakan yang menunjukkan perilaku tertib dan patuh pada berbagai ketentuan dan peraturan. Seorang pemuda (mahasiswa) dituntut disiplin dan patuh pada ketentuan dan undang-undang yang ada serta 
menghargai waktu yang ada. Seorang pemuda harus tepat waktu dalam segala hal. Tepat waktu dalam mengikuti perkuliahan, tepat waktu dalam mengumpulkan tugas-tugas kuliah. Disiplin akan membimbing kita untuk hidup dengan tertib. Nilai karakter disiplin dapat ditanamkan kepada mahasiswa dengan cara mengingatkan agar mahasiswa hadir tepat waktu dan tidak terlambat, termasuk juga dalam mengumpulkan tugas-tugasnya. Kegiatan ini dapat dilihat dari tingkat kedisiplinan mahasiswa dalam setiap kehadiran kuliah dan tingkat ketepatan waktu mahasiswa dalam mengumpulkan tugas-tugas. Dosen perlu membuat daftar bukti pengumpulan tugas dan daftar pengamatan kehadiran mahasiswa dalam perkuliahan.

Nilai kerja keras merupakan perilaku yang menunjukkan upaya sungguhsungguh dalam mengatasi berbagai hambatan belajar dan tugas, serta menyelesaikan tugas dengan sebaik-baiknya. Saat ini tuntutan kerja keras menjadi satu bentuk keharusan agar hidup kita berhasil. Tanpa kerja keras seorang mahasiswa tidak akan pernah berhasil dalam kehidupannya. Nilai karakter kerja keras dapat ditanamkan dengan cara mengharuskan mahasiswa mengerjakan tugas-tugasnya secara sungguh-sungguh. Kegiatan ini bisa dipantau dari sejauh mana kesungguhan mahasiswa dalam mengikuti proses perkuliahan dan pengerjaan tugas-tugas. Kesungguhan dalam mengerjakan tugas-tugas dapat dipantau dari keseriusan mahasiswa dalam menyelesaikan tugas yang diberikan oleh dosen. Dosen perlu memberikan reward kepada mahasiswa yang sungguhsungguh dalam mengerjakan tugas-tugasnya.

Nilai kreatif lebih mengasu kepada kegiatan berpikir dan melakukan sesuatu untuk menghasilkan cara atau hasil baru dari sesuatu yang telah dimiliki. Kreativitas sangat diharapkan muncul dari kaum muda (mahasiswa). Pemerintah memberikan satu wadah kegiatan bagi mahasiswa dalam bentuk Program Kreativitas Mahasiswa (PKM) yang setiap tahunnya diadakan kegiatan Pekan Ilmiah Mahasiswa Nasional (PIMNAS). Mahasiswa dituntut kreatif menemukan sesuatu hal yang baru yang bermanfaat bagi masyarakat maupun bagi mahasiwa. 
Nilai karakter kreatif dapat ditanamkan dengan cara memberikan tugas-tugas kepada mahasiswa secara kreatif dalam bentuk menyusun sebuah proposal PKM. Kegiatan ini dapat dilakukan dengan cara memantau keikutsertaan mahasiswa dalam program kreativitas mahasiswa. Ada kewajiban seorang mahasiswa untuk membuat proposal PKM. Melalui judul-judul tersebut dosen dapat memberikan penilaian sejauh mana mahasiswa tersebut kreatif atau tidak.

Nilai cinta air merupakan cara berpikir, bersikap, dan berbuat yang menunjukkan kesetiaan, kepedulian, dan penghargaan yang tinggi terhadap bahasa, lingkungan fisik, sosial, budaya, ekonomi, dan politik bangsa. Seorang pemuda atau mahasiswa harus memiliki rasa cinta tanah air yang diwujudkan dengan jiwa nasionalisme. Jiwa nasionalisme ini akan mendasari seseorang untuk membangun bangsanya dan melindungi segala gangguan yang merongrong NKRI. Nilai karakter cinta tanah air dapat ditanamkan dosen dengan cara memberikan tugas menulis kepada mahasiswa. Mahasiswa diminta menuliskan essay tentang nasionalisme, tentang sikap-sikapnya terhadap tanaah air, bela Negara, dan berbagai hal yang berhubungan dengan masalah cinta tanah air.

Nilai gemar membaca merupakan suatu kebiasaan menyediakan waktu untuk membaca berbagai bacaan yang memberikan kebajikan bagi dirinya. Seorang mahasiswa dituntut selalu membaca dan membaca. Membaca sebagai upaya untuk memperoleh informasi yang akan memperkaya ilmu pengetahuan dan menambah pengalaman yang dimilikinya. Nilai karakter gemar membaca dapat ditanamkan dengan cara mengajak mahasiswa ke perpustakaan. Mahasiswa diberi tugas untuk membuat resensi buku, menulis laporan membaca sebuah buku, dan menganalisis beberapa artikel ilmiah. Menganalisis artikel ilmiah yang disediakan oleh dosen akan menuntut mahasiswa untuk gemar membaca.

Nilai peduli lingkungan merupakan sikap dan tindakan yang selalu berupaya mencegah kerusakan pada lingkungan alam di sekitarnya, dan mengembangkan upaya-upaya untuk memperbaiki kerusakan alam yang sudah terjadi. Mahasiswa harus peduli pada lingkungan di sekitarnya. Tanggap terhadap 
situasi yang terjadi di lingkungannya, termasuk lingkungan sosialnya. Nilai karakter peduli lingkungan dapat ditanamkan dengan cara memberikan tugas kepada mahasiswa untuk melakukan kegiatan pengamatan di sekitar lingkungannya dikaitkan dengan bidang ilmu yang dipelajarinya. Selanjutnya mahasiswa diminta membuat satu permasalahan yang saat ini menjadi topik perbincangan di masyarakat untuk dijadikan satu topik artikel atau makalah dan mengaitkan dengan berbagai teori yang ada dengan hasil pengamatannya. Perpaduan kegiatan pengamatan dan kegiatan mengkaji berbagai teori yang ada akan menghasilkan sebuah tulisan, yaitu menulis artikel atau menulis makalah.

Nilai tanggung jawab merupakan sikap dan perilaku seseorang untuk melaksanakan tugas dan kewajibannya, yang seharusnya dilakukan, terhadap diri sendiri, masyarakat, lingkungan (alam, sosial dan budaya), negara dan Tuhan Yang Maha Esa. Seorang pemuda (mahasiswa) harus memiliki sikap tanggung jawab terhadap apa yang telah dilakukan, termasuk apa yang ditulis atau apa yang diucapkan. Nilai karakter tanggung jawab dapat ditanamkan melalui perkuliahan MKU Bahasa Indonesia. Mahasiswa diminta mempertanggungjawabkan hasil tulisannya dalam bentuk presentasi hasil pengamatannya, mempresentasikan proposal PKM yang ditulisnya. Dalam konsep ini, bentuk tanggung jawab mahasiswa masih terbatas sejauh mana mahasiswa bertanggung jawab atas hasil tulisannya, pendapatnya, serta berani jujur menyampaikan bahwa pendapatnya itu adalah pendapat dari orang lain (melatih agar mahasiswa tidak melakukan kegiatan plagiat).

\section{SIMPULAN}

Pendidikan karakter menjadi daya pendorong bagi para mahasiswa untuk menjadi intelektual muda bangsa yang memiliki kepribadian unggul, sebagaimana dimuat dalam undang-undang pendidikan nasional. Tujuan pendidikan karakter adalah penanaman nilai dalam diri mahasiswa dan pembaharuan tata kehidupan bersama yang lebih menghargai kebebasan individu. 
Pendidikan karakter yang perlu dikembangkan adalah penanaman nilai dalam diri mahasiswa, baik itu nilai ketuhanan, nilai kemanusiaan, maupun nilai tentang alam. Pembiasaan dan pembentukan sikap akan hal-hal yang baik akhirnya akan membentuk karakter mahasiswa.

Bentuk-bentuk yang bisa dilakukan oleh dosen dalam menanamkan nilai karakter sebagai berikut: (1) Nilai religius di kalangan mahasiswa melalui perkuliahan MKU Bahasa Indonesia, salah satunya adalah dengan ungkapan rasa syukur dan bangga menggunakan bahasa Indonesia ini bisa dituangkan dalam bentuk tulisan essay; (2) Nilai karakter kejujuran bisa ditanamkan melalui satu bentuk tugas menulis yang diberikan oleh dosen. Mahasiswa harus jujur menuliskan apa yang telah dibacanya di perpustakaan; (3) Nilai karakter disiplin dapat ditanamkan kepada mahasiswa dengan cara mengingatkan agar mahasiswa hadir tepat waktu dan tidak terlambat, termasuk juga dalam mengumpulkan tugastugasnya; (4) Nilai karakter kerja keras dapat ditanamkan dengan cara mengharuskan mahasiswa mengerjakan tugas-tugasnya secara sungguh-sungguh; (5) Nilai karakter kreatif dapat ditanamkan dengan cara memberikan tugas-tugas kepada mahasiswa secara kreatif dalam bentuk menyusun sebuah proposal PKM. Melalui judul-judul tersebut dosen dapat memberikan penilaian sejauh mana mahasiswa tersebut kreatif atau tidak; (6) Nilai karakter cinta tanah air dapat ditanamkan dosen dengan cara memberikan tugas menulis kepada mahasiswa berupa essay tentang nasionalisme, tentang sikap-sikapnya terhadap tanaah air, bela Negara, dan berbagai hal yang berhubungan dengan masalah cinta tanah air; (7) Nilai karakter gemar membaca dapat ditanamkan dengan cara diberi tugas untuk menulis resensi buku, menulis laporan membaca sebuah buku, dan menganalisis beberapa artikel ilmiah; (8) Nilai karakter peduli lingkungan dapat ditanamkan dengan cara memberikan tugas kepada mahasiswa untuk melakukan kegiatan observasi di sekitar lingkungannya dikaitkan dengan bidang ilmu yang dipelajarinya. Perpaduan kegiatan observasi dan kegiatan mengkaji berbagai teori yang ada akan menghasilkan sebuah tulisan, yaitu menulis artikel atau menulis 
makalah; dan (9) Nilai karakter tanggung jawab dapat ditanamkan melalui perkuliahan MKU Bahasa Indonesia dengan cara mempresentasikan hasil pengamatannya, mempresentasikan makalahnya, dan mempresentasikan proposal PKM yang ditulisnya.

\section{DAFTAR PUSTAKA}

Asmani, Jamal Ma'mur. 2011. Buku Panduan Internalisasi Pendidikan Karakter di Sekolah. Jogjakarta: Diva Press.

Bali, Markus Masan. 2013. "Peran Dosen dalam Mengembangkan Karakter Mahasiswa." dalam Humaniora, Vol 4. No. 2, Oktober 2013: 800-810.

Darwis, Kamsinah. 2013. Sinergi Pengajaran Bahasa, Budaya, dan Agama dalam Pembentukan Karakter. Dalam Putra, Heddy Shri Ahimsa, dkk (ed). Bahasa, Budaya dan Karakter Manusia. Yogyakarta: Gama Media.

Khan, Yahya. 2010. Pendidikan Karakter Berbasis Potensi Diri. Yogyakarta: Pelangi Publishing.

Pateda, Lamsike. 2014. "Pembinaan Karakter Mahasiswa Melalui Perkuliahan Bahasa Indonesia" dalam TADBIR. Jurnal Manajemen Pendidikan Islam IAIN Sultan Amal Gorontalo. Nomor 2, Februari 2014. Halaman 79-85.

Patria, Bekti. 2010. "Pembelajaran Apresiasi Sastra Sebagai Wahana Penanaman Karakter kepada Siswa". Diunduh tanggal 28 Februari 2012 dari laman http://bektipatria.wordpress.com/2010/09/01/sastra-dan-pendidikan-karakter/

Putra, Heddy Shrihimsa, dkk. 2013. Bahasa, Budaya dan Karakter Manusia. Yogyakarta: Gama Media.

Salam, Burhanudin. 2000. Etika Individual Pola dasar Filsafat Moral. Jakarta: Rineka Cipta.

Samani, Muchlas dan Hariyanto. 2012. Konsep dan Model Pendidikan Karakter. Bandung: Remaja Rosdakarya. 
Santoso, Agus Budi, Dwi Rohman Soleh, dan Eni Winarsih. 2015. "Pengembangan Buku Ajar MKU Bahasa Indonesia Berbasis Karakter dengan Mengoptimalkan Kemampuan Menulis Ilmiah Bagi Mahasiswa IKIP PGRI Madiun.” Laporan Hibah Bersaing Tahun 1. Madiun: IKIP PGRI Madiun.

Sofyan, Herminarto. 2011. Implementasi Pendidikan Karakter Melalui Kegiatan Kemahasiswaan (dalam https://www.scribd.com/doc/296682810/BUKUPendidikan-Karakter-bagi-Mahasiswa-UNY-pdfdiunduh pada 4 Agustus 2016).

Bahasa, Sastra, dan Pemuda 